\title{
Analysis of a Thermotoga maritima DNA fragment encoding two similar thermostable cellulases, CelA and CelB, and characterization of the recombinant enzymes
}

\author{
Wolfgang Liebl, ${ }^{2}$ Peter Ruile, ${ }^{1}$ Karin Bronnenmeier, ${ }^{1}$ Katrin Riedel, \\ Friedrich Lottspeich ${ }^{2}$ and Ingrid Greif'
}

Author for correspondence: Wolfgang Liebl. Tel: +4989 28922378. Fax: +498928922360.

\footnotetext{
1 Institut für Mikrobiologie, Technische Universitat München, Arcisstraße 21, D-80290 München, Germany

2 Max-Planck-Institut für Biochemie, Martinsried, Germany
}

\begin{abstract}
Recombinant Escherichia coli clones displaying thermostable $\beta$-glucanase activity were isolated from two different gene libraries of the hyperthermophilic bacterium Thermotoga maritima MSB8 (DSM 3109), and the nucleotide sequence of a 1,4- $\beta$-glucanase gene designated celA was determined. Amino-terminal sequencing of cellulase I previously detected in $T$. maritima cells indicated that the celA gene encodes this $\beta$-glucanase, which is now designated CelA. CelA, which has a calculated molecular mass of $29732 \mathrm{Da}$, was purified from a recombinant $E$. coli strain to apparent homogeneity as judged by SDS-PAGE with a $\mathbf{4 4 \%}$ yield. The enzyme was most active against soluble substrates such as mixed-linkage $\beta$-glucan and $\mathrm{CM}$ cellulose. CelA displayed remarkable thermostability, which was enhanced in the presence of high concentrations of salt. Downstream of the celA gene we found a second open reading frame, ce/B, whose nucleotide sequence was $58 \%$ identical to celA. Experimental proof that celB also encodes a $\beta$-glucanase was obtained by separation from celA and expression in $E$. coli under the control of an efficient host promoter. According to the deduced amino acid sequences, CelB, in contrast to CelA, contains a signal peptide at the amino terminus. CelB and CelA had similar substrate specificities and temperature optima, but differed in their pH optima. Also, the addition of salt had a less stabilizing effect on CelB than on CelA. Nine 30 bp direct repeats, each itself representing a sequence with imperfect dyad symmetry, were detected upstream of the celA-ce/B cellulase gene cluster.
\end{abstract}

Keywords: cellulase, $\beta$-glucanase, nucleotide sequence, purification, thermostability

\section{INTRODUCTION}

Two Thermotoga species, i.e. Thermotoga maritima and Thermotoga neapolitana, represent the most thermophilic organotrophic eubacteria described to date. They grow fermentatively at temperatures up to $90^{\circ} \mathrm{C}$ (Huber \& Stetter, 1992). Thermotoga species are able to utilize various carbohydrates for growth, including the polymers starch, xylan and cellulose (Huber \& Stetter, 1992; own unpublished results). Enzymes investigated from these species so far have generally displayed high thermostability (e.g. Gabelsberger et al., 1993a, b; Jaenicke, 1993; Liebl et al., 1992; Ostendorp et al., 1993; Rutter-

The EMBL accession number for the sequence reported in this paper is Z69341. smith \& Daniel, 1991; Wrba et al., 1990), which makes them potentially interesting candidates for the investigation of protein stability as well as for biotechnological applications.

Cellulose, the major structural polysaccharide of plant cell walls, consists of D-glucose units linked together to linear chains via $1,4-\beta$-glycosidic bonds. The breakdown of cellulose by cellulolytic micro-organisms is notmally accomplished in two steps. First, cellulases act by hydrolysis of the polymer chains. Then, in a second step, the cello-oligosaccharides liberated by cellulase action are degraded further by $\beta$-glucosidases or cellodextrin phosphorylases.

The cloning, sequence analysis and purification of a thermostable $\beta$-glucosidase which may be involved in the 
final step of the breakdown of cellulose or cellodextrins to glucose by $T$. maritima MSB8 has been reported (Gabelsberger et al., 1993a, b; Liebl et al., 1994). Ruttersmith \& Daniel (1993) have characterized a $\beta$-glucosidase of Thermotoga sp. strain FjSS3-B.1. Only three reports about Thermotoga enzymes that hydrolyse $1,4-\beta$-glycosidic bonds of polymeric $\beta$-glucans are available. One deals with an exoglucanase $(1,4-\beta$-D-glucan cellobiohydrolase; EC 3.2.1.91) from the culture supernatant of Thermotoga sp. strain FjSS3-B.1 (Ruttersmith \& Daniel, 1991). Dakhova et al. (1993) have reported the cloning of $T$. neapolitana DNA fragments that confer $\beta$-glucanase production upon $E$. coli transformants. Finally, Bronnenmeier et al. (1995) demonstrated the presence of two cellulases, cellulase $I$ and $I I$, in the crude cellular extract of T. maritima strain MSB8. Both enzymes were able to cleave CM-cellulose, $\beta$-glucan and $p$-nitrophenyl $\beta$-Dcellobioside. Cellulase I was classified as an endoglucanase (1,4- $\beta$-D-glucan glucanohydrolase; EC 3.2.1.4), while cellulase II also attacked microcrystalline cellulose, yielding cellobiose and glucose, and therefore has exo-1,4- $\beta$-Dglucanase activity (Bronnenmeier et al., 1995). Primary structures of cellulases from hyperthermophilic organisms have not been reported to date. We now describe the isolation and analysis of a $T$. maritima MSB8 DNA fragment encoding $\beta$-glucanase production and present the results of the characterization of an extremely thermostable cellulase purified from a recombinant E. coli strain.

\section{METHODS}

Strains, plasmids and substrates. The cloning vector/host strain combinations used for gene library constructions and expression studies were pSU1/E. coli M5219 (Schüller et al., 1985; Remaut et al., 1981), pUN121/E. coli JM83 (Nilsson et al., 1983; Yanisch-Perron t tal., 1985), pT7-7/E. coli BL21 (USB; Studier \& Moffatt, 1986) and PWLQ2/E. coli XL1-Blue (Liebl et al., 1992; Stratagene). E. coli strains were toutinely grown in Luria-Bertani medium (LB; $1 \%, \mathrm{w} / \mathrm{v}$, peptone; $0.5 \% \mathrm{w} / \mathrm{v}$, yeast extract; $0.5 \%, w / v, \mathrm{NaCl} ; \mathrm{pH} 7.2)$ supplemented with $100 \mu \mathrm{g}$ ampicillin $\mathrm{ml}^{-1}$ or $12 \mu \mathrm{g}$ oxytetracycline $\mathrm{ml}^{-1}$ where appropriate. Cellulase enzyme substrates were purchased from Sigma (CM-cellulose, low viscosity; lichenan; $p$-nitrophenyl $\beta$ D-cellobioside), Serva (microcrystalline cellulose Avicel, $0.02 \mathrm{~mm}$; cellulose MN300, 0.002 0.02 mm), Fluka (oat spelts xylan) and Megazyme (barley $\beta$-glucan). Acid-swollen Avicel was prepared by incubating Avicel in concentrated hydrochloric acid with continuous agitation for $2 \mathrm{~h}$.

DNA methodology, sequencing and computer analysis. Plasmid DNA isolation, transformation of E. coli, DNA modifications and Southern hybridization analysis were done with standard techniques (Ausubel et al., 1987). Enzymes for DNA modification were purchased from Boehringet Mannheim or Pharmacia. The nucleotide sequence was determined on both strands of the plasmid employing the DIG Taq DNA sequencing kit (Boehringer Mannheim). Computer analysis of the DNA sequences was done with programs of the University of Wisconsin Genetics Computer Group (UWGCG) software package (Devereux et al., 1984) for Unix version 7.3.

Protein analytical methods. Protein concentrations were measured by the method of Bradford (1976) with bovine serum albumin as a standard. Protein molecular masses were determined via discontinuous SDS-PAGE as described by Laemmli (1970). Unless mentioned otherwise, samples were mixed with 1 vol. sample buffer $(15 \%, \mathrm{v} / \mathrm{v}$, glycerol; $5 \%, \mathrm{v} / \mathrm{v}$, $\beta$-mercaptoethanol; $2.3 \%, \mathrm{w} / \mathrm{v}$, SDS; $62.5 \mathrm{mM}$ Tris $/ \mathrm{HCl}$, $\mathrm{pH} 6.8 ; 0.05 \%, \mathrm{w} / \mathrm{v}$, bromphenol blue) and boiled for $5 \mathrm{~min}$ prior to application.

Preparation of crude extracts. A lysozyme/freeze thaw method was employed for the rapid preparation of crude extracts for the screening of the gene library and for initial enzyme characterization. For this purpose, the clones were grown in $50 \mathrm{ml} \mathrm{LB}$ broth with ampicillin selection. The cells were harvested, washed with $5 \mathrm{mi} 50 \mathrm{mM}$ Tris/ $\mathrm{HCl}, \mathrm{pH} 8$, resuspended in $1.5 \mathrm{ml} 50 \mathrm{mM}$ Tris $/ \mathrm{HCl}, \mathrm{pH} 8.0,10 \mathrm{mM}$ EDTA, and treated with $100 \mu \mathrm{g}$ lysozyme $\mathrm{ml}^{-1}, 10 \mu \mathrm{g}$ DNasel $\mathrm{ml}^{-1}$ and $10 \mu \mathrm{g}$ RNase $\mathrm{A} \mathrm{ml} \mathrm{m}^{-1}$ for $60 \mathrm{~min}$ at $20^{\circ} \mathrm{C}$. Lysis was enhanced by a threefold freeze $\left(-20^{\circ} \mathrm{C}\right)$-thaw procedure. Supernatants of the lysates were obtained after a $40 \mathrm{~min}$ centrifugation step $\left(40000 \mathrm{~g}, 30 \mathrm{~min}, 4^{\circ} \mathrm{C}\right)$. In order to obtain an enzyme preparation entiched in $\beta$-glucanase for further characterization, the crude extract was heated at $70^{\circ} \mathrm{C}$ for $30 \mathrm{~min}$, cooled on ice, and then cleared of precipitated host proteins by centrifugation.

Detection of $\beta$-glucanase activity on plates and after SDSPAGE. Clones producing thermoactive endoglucanase were identified after growing them on CM-cellulose plates $(10 \mathrm{~g}$ tryptone, $6 \mathrm{~g}$ yeast extract, $2.5 \mathrm{~g} \mathrm{NaCl}, 2 \mathrm{~g} \mathrm{CM}$-cellulose medium viscosity, $6 \mathrm{~g}$ agar and $1000 \mathrm{ml} \mathrm{H}_{2} \mathrm{O}, \mathrm{pH} 7.2$ ) at $37^{\circ} \mathrm{C}$. The plates were incubated at $60-70^{\circ} \mathrm{C}$ for $3-4 \mathrm{~h}$ and subsequently stained with $0.1 \%(\mathrm{w} / \mathrm{v})$ Congo red $(15 \mathrm{~min})$. Excess dye was removed with $1 \mathrm{M} \mathrm{NaCl}(10 \mathrm{~min})$. Location of enzymic activity in protein bands after SDS-PAGE was accomplished after separation of enzyme samples in an SDS-polyacrylamide gel containing $0.1 \%(\mathrm{w} / \mathrm{v}) \mathrm{CM}$-cellulose. The gel was washed at ambient temperature first for $30 \mathrm{~min}$ in a mixture $(4: 1, \mathrm{v} / \mathrm{v})$ of $100 \mathrm{mM}$ succinate buffer, $\mathrm{pH} 6.0$, and 2-propanol, then for another $30 \mathrm{~min}$ in $100 \mathrm{mM}$ succinate buffer, $\mathrm{pH} 6.0$. During the whole period, the wash solution was renewed every $15 \mathrm{~min}$. The gel was submerged in $100 \mathrm{mM}$ succinate buffer, pH $6 \cdot 0$, at $60^{\circ} \mathrm{C}$ for $30-120 \mathrm{~min}$. Subsequently, the gel was stained with $0.1 \%$ ( $w / v$ ) Congo red for $20 \mathrm{~min}$ and excess dye was removed by washing with $1 \mathrm{M}$ sodium chloride.

Assay of enzyme activity. The $\mathrm{pH}$ values of buffers were adjusted at the temperatures of use. Unless mentioned otherwise, enzyme assays were done in duplicate at $85^{\circ} \mathrm{C}$ in $0.5 \mathrm{ml}$ reaction mixtures containing $50 \mathrm{mM}$ MES buffer, $\mathrm{pH} 6.0$, and $4 \mathrm{mM} p$-nitrophenyi $\beta$-D-cellobioside, $0.5 \%$ (w/v) soluble polysaccharide substrates or $1 \%(\mathrm{w} / \mathrm{v})$ non-soluble substrates. The enzymic liberation of reducing groups was determined with the dinitrosalicylic acid reagent (Bernfeld, 1955). One unit of enzyme activity was defined as the amount of enzyme needed to release $1 \mu \mathrm{mol}$ glucose-equivalent teducing groups $\mathrm{min}^{-1}$. Nonenzymic hydrolysis of the substrates at elevated temperatures was corrected for with appropriate controls in every experiment. Stability at elevated temperatures was measured by determination of residual activity with the standard assay after preincubation of enzyme samples in $50 \mathrm{mM}$ MES buffer, $\mathrm{pH} 6.0$, at various temperatures and $\mathrm{NaCl}$ concentrations.

TLC of oligosaccharides. TLC of $\beta$-glucan degradation products was done by an ascending technique on $0 \cdot 2 \mathrm{~mm}$ silica-gel-coated aluminum sheets (type 60; Merck). Sepatation of the cellooligosaccharides was achieved by three consecutive ascents using a solvent system consisting of chloroform/acetic acid/ water ( $5: 7: 1$, by vol.). Carbohydrate spots were visualized by spraying the chromatogram with aniline-diphenylamine reagent as described previously (Liebl et al., 1992).

Construction of pT7-7-celA. Two synthetic oligonucleotide primers with the nucleotide sequences 5 -GGCATTCCATA- 
Table 1. Purification of recombinant CelA

Enzyme activities are expressed as CM-cellulose-hydrolysing activities measured in 30 min assays at $\mathrm{pH} 6.0$ at $85^{\circ} \mathrm{C}$.

\begin{tabular}{|c|c|c|c|c|c|}
\hline Step & $\begin{array}{l}\text { Protein } \\
\text { (mg) }\end{array}$ & $\begin{array}{c}\text { Total } \\
\text { activity } \\
\text { (U) }\end{array}$ & $\begin{array}{l}\text { Specific } \\
\text { activity } \\
\left(\mathrm{U} \mathrm{mg}^{-1}\right)\end{array}$ & $\begin{array}{c}\text { Purification } \\
\text { (-fold) }\end{array}$ & $\begin{array}{c}\text { Yield } \\
(\%)\end{array}$ \\
\hline Cleared lysate & 4002 & 11090 & $2 \cdot 76$ & $1 \cdot 0$ & 100 \\
\hline $\begin{array}{l}\text { Heat treatment } \\
\left(20 \text { min at } 75^{\circ} \mathrm{C}\right)\end{array}$ & 228 & 8740 & $40 \cdot 4$ & $14 \cdot 6$ & 79 \\
\hline After Q-Sepharose & $56 \cdot 4$ & 6470 & $71 \cdot 9$ & $26 \cdot 5$ & 58 \\
\hline After Phenyl-Sepharose & $16 \cdot 8$ & 4900 & 291 & 105 & 44 \\
\hline
\end{tabular}

TGG'TACTGATGACAAAACCG-3' and 5'-CGGAATTCA'TCTCTCACCTCCAGATC-3', designated celA-V and celA$\mathrm{R}$, respectively, were constructed on the basis of the nucleotide sequence of the cel $A$ gene. These primers were used in PCRaided amplification of the celA-coding region. The reaction mixture contained $200 \mathrm{ng}$ EcoRI-linearized PTEGI.-H as the template DNA, 50 pmol of each primer, deoxynucleotide triphosphates (200 $\mu \mathrm{M}$ each), $2 \cdot 5 \mathrm{U}$ Pyrococcus furiosus (Pfu) DNA polymerase and $10 \mu \mathrm{l} 10 \times$ Pfu reaction buffer (both Stratagene) in a total volume of $0 \cdot 1 \mathrm{ml}$. The template strands were separated at $94{ }^{\circ} \mathrm{C}$ (3 min) before starting 40 reaction cycles $\left(94^{\circ} \mathrm{C} / 30 \mathrm{~s}\right.$, $\left.51^{\circ} \mathrm{C} / 2 \mathrm{~min}, 72^{\circ} \mathrm{C} / 4 \mathrm{~min}\right)$. The PCR primers celA-V and cel A$\mathrm{R}$ contained recognition sites for the restriction endonucleases $N d e \mathrm{I}$ and $E c o \mathrm{RI}$, respectively, which were used for the in-frame fusion of the $\operatorname{col} A$ open reading frame to the start codon downstream of the $\mathrm{P}_{\mathrm{T} 7}$ promoter and ribosome-binding site of expression vector pT7.7 pretreated with the same restriction enzymes. The correct insertion of the PCR product into pT7-7 was verified by nucleotide sequence analysis. The resulting plasmid, designated p T7-7-celA, was transformed into an $E$. coli BL21 expression host strain with an IP'TG-inducible chromosomal copy of the RNA polymerase gene of phage T7 (Studier \& Moffatt, 1986).

Purification of recombinant CelA from E. coli BL21(pT7-7celA) and cellulase I from $T$. maritima MSB8 cells. E. coli BI 21 (pT7-7-celA) was inoculated $(1 \%, v / v)$ into 51 baffled flasks containing $2512 \times$ LB medium supplemented with $100 \mu \mathrm{g}$ ampicillin $\mathrm{ml}^{-1}$. After growth for $14 \mathrm{~h}$ on a rotary shaker at $35^{\circ} \mathrm{C}$, the cells were harvested, washed and resuspended with $20 \mathrm{mM}$ Tris $/ \mathrm{HCl}, \mathrm{pH} 7 \cdot 0$. The cells were lysed by passage of the suspension through a French pressure cell (American Instrument Company) at $6.9 \mathrm{MPa}$. Remaining whole cells and debris were removed by centrifugation $(27000 \mathrm{~g}, 30 \mathrm{~min})$. The cleared lysate was incubated at $75^{\circ} \mathrm{C}$ for $20 \mathrm{~min}$ and centrifuged again in order to precipitate the majority (about $94 \%$ ) of heat-labile host cell proteins. The supernatant, which contained nearly $80 \%$ of the initial amount of thermostable cellulase, was adjusted to $\mathrm{pH} 8 \cdot 0$ and loaded onto a Q-Sepharose fast-flow column (Pharmacia). Elution was achieved with a 10 bed volume gradient of $0-0.5 \mathrm{M}$ sodium chloride in $20 \mathrm{mM}$ Tris $/ \mathrm{HCl}, \mathrm{pH} 8 \cdot 0$. The fractions with thermostable $\mathrm{CM}$-cellulase activity were pooled, adjusted to $1.5 \mathrm{M}$ ammonium chloride and $50 \mathrm{mM}$ Tris $/ \mathrm{HCl}, \mathrm{pH} 8.0$, and applied to a HiLoad PhenylSepharose column (Pharmacia). The enzyme was eluted from the column with a 10 bed volume gradient of $1.5-0 \mathrm{M}$ ammonium chloride in $50 \mathrm{mM}$ Tris $/ \mathrm{HCl}, \mathrm{pH} 8 \cdot 0$. Finally, $16.8 \mathrm{mg}$ purified recombinant CelA was obtained with a yield of $44 \%$ (see Table 1). Cellulase I from cells of $T$. maritima for comparison with recombinant CelA was prepared as described previousiy (Bronnenmeier et al., 1995). Its amino-terminal amino acid sequence was determined by Edman degradation using a gas-phase amino acid Sequenator model $477 \mathrm{~A}$ (Applied Biosystems).

\section{RESULTS AND DISCUSSION}

\section{Isolation of T. maritima MSB8 genes encoding thermostable $\beta$-glucanase activity}

Two previously constructed libraries of $T$. maritima genomic DNA (Gabelsberger et al., 1993a; Ostendorp et al., 1993) were screened for clones producing thermostable CM-cellulose-hydrolysing activity. The first, pSU1based, library was screened after preparing crude lysates of pools, consisting of 12 clones each, with the lysozyme/ freeze-thaw method described above. The lysates were tested for thermostable $\beta$-glucan- and CM-cellulosehydrolysing activity. Positive pools were investigated further by checking the single clones for activity in the same way. Upon screening several thousand pools by this procedure, eight independent clones were finally obtained which displayed thermostable hydrolytic activity against barley $\beta$-glucan and CM-cellulose. The recombinant plasmids of these clones were named pTG1, 2, 5, 6, 7, 8, 9 and 10 . The other, pUN121-based, library was screened with the plate assay described in the Methods after replicaplating clones onto agar plates containing $0.2 \% \mathrm{CM}$ cellulose. Five different recombinant plasmids, designated PTEGL-A, $-\mathrm{G},-\mathrm{H},-\mathrm{P}$ and $-\mathrm{R} 2$, were isolated from positive clones of this screen. Restriction analysis of the $\beta$ glucanase plasmids revealed that the insert fragments of all of the pTG plasmids and at least three of the pTEGL plasmids ( $P$ TEGL-A, $-\mathrm{G}$ and $-\mathrm{H}$ ) overlapped (data not shown). The DNA segment common to all of these plasmids had a length of about $0.9 \mathrm{~kb}$, representing a polypeptide coding capacity of up to 300 residues or about $35 \mathrm{kDa}$. These numbers are consistent with the molecular masses determined via SDS-PAGE for the known $T$. maritima cellulases I and II (about $27 \mathrm{kDa}$ and $29 \mathrm{kDa}$, respectively ; Bronnenmeier et al., 1995). pTEGL$\mathrm{P}$ and $\mathrm{pTEGL-R2}$, which may contain additional CMcellulase genes, were not investigated further in this study. 


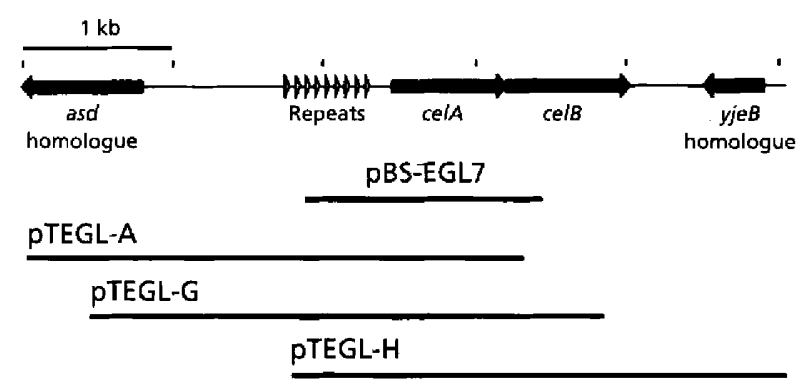

Fig. 1. Genetic map of an approximately $5 \mathrm{~kb}$ large segment of the T. maritima MSB8 genome. Segments thereof cloned in various recombinant plasmids (see text) are drawn as solid lines.

\section{Nucleotide sequence analysis}

Primary structures of cellulases or their genes from hyperthermophilic organisms have not been reported to date. Therefore, it was of interest to sequence the cloned cellulase-encoding DNA fragment of $T$. maritima. An EcoRI-SalI fragment of PTG7 containing the complete $1.7 \mathrm{~kb}$ Sau3A/partial $T$, maritima chromosoma1 DNA insert of this plasmid was cloned into the multiple cloning site of the sequencing vector pBluescript $\mathrm{KS}(+)$ (Stratagene), yielding pBS-EGL7 (Fig. 1). After constructing various deletion derivatives, the nucleotide sequence of both strands of the insert was determined. The T. maritima chromosomal DNA fragment present in pBS-EGL7 and in pTG7 represents the sequence between the $S_{a n 3} \mathrm{~A}$ sites at positions 469 and 2131 which contains one complete open reading frame (residues 1107-1880), termed col A.

The amino-terminal amino acid sequence of cellulase I purified from cells of $T$. maritima MSB8 as described previously (Bronnenmeier et al., 1995) was determined in order to find out if this enzyme is encoded by $c e / A$. Indeed, the sequence obtained, MVLMTKPGTSDF, supports this view since it is found at positions 1 through 12 of the CelA primary structure deduced from the nucleotide sequence of the gene.

The nucleotide sequence analysis of the pBS-EGL7 insert revealed several 30 bp direct repeats upstream of $c e l A$ and an incomplete reading frame downstream of cel $A$. Therefore, the sequence was extended in both directions via primer walking using the $\beta$-glucanase plasmids pTEGL$A,-G$ and $-H$, whose inserts overlap with the pBSTEGL7 insert (Fig. 1), as templates. In this way, the contiguous $2.8 \mathrm{~kb}$ sequence of the $\Gamma$. maritima MSB8 genome shown in Fig. 2 was obtained. The now completed second open reading frame was named $c e l B$. It is presently not known if $c e l B$ encodes the second cellulase purified from cells of $T$. maritima, i.e. cellulase II (Bronnenmeier et al., 1995), because an amino-terminal sequence of this enzyme is not available. The coding regions of $\operatorname{cel} A$ and $c e l B$ were $58 \%$ identical at the nucleotide sequence level. Using sequencing primers constructed to anneal to sequences of the vector pUN121 flanking the inserts, we also obtained single-strand nucleotide sequences of the ends of the inserts of PTEGL-

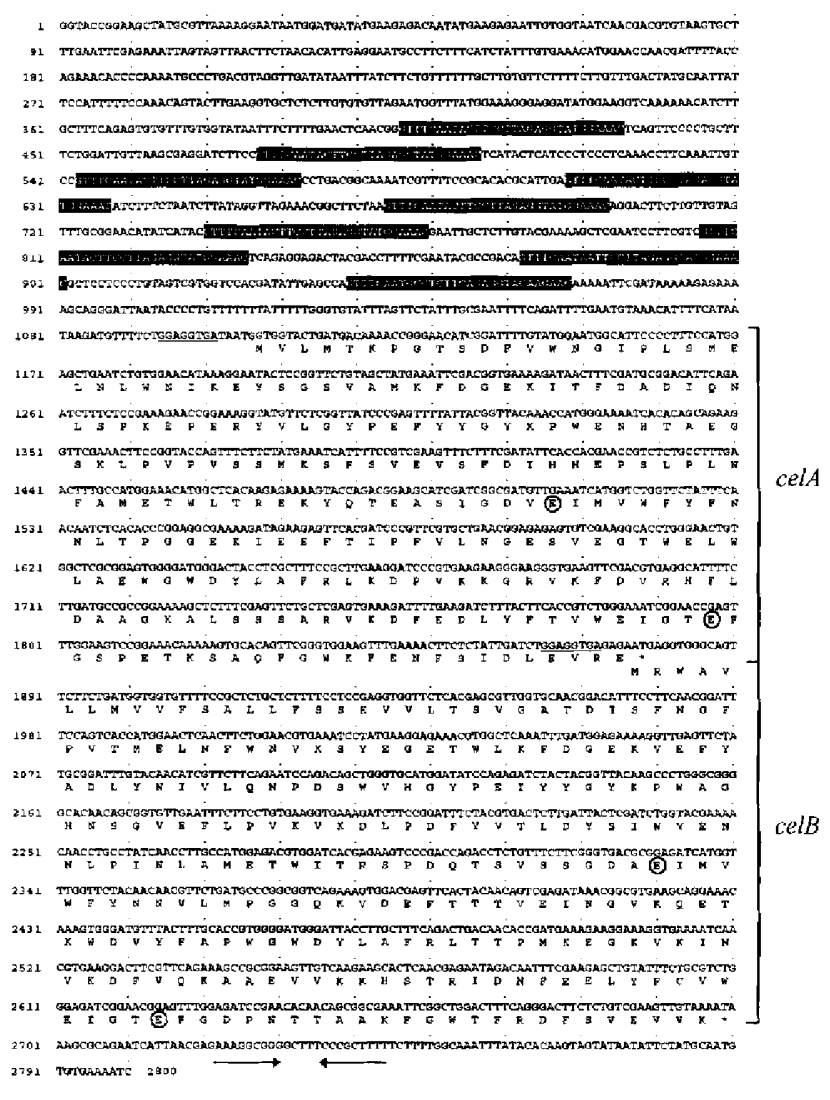

Fig. 2. Nucleotide sequence of the $T$, maritima cellulase gene region and deduced primary structures of $\mathrm{Ce} / \mathrm{A}$ and $\mathrm{Ce} / \mathrm{B}$. The putative ribosome-binding sites are underlined. The putative catalytic glutamate residues are circled. Nine $30 \mathrm{bp}$ repeats are shown as black boxes with white letters. An inverted repeat which could represent a transcription termination structure is indicated by arrows.

$A,-G$ and $-H$. Based on the analysis of these data, we were able to assemble a gene map of an approximately $5 \mathrm{~kb}$ region of the $T$. maritima genome (Fig. 1). Two open reading frames, both in the opposite orientation to $c e l A-c e l B$, were found whose putative translation products shared significant amino acid sequence similarity with known protein sequences. A truncated open reading frame upstream of cel $A-c e l B$ could be part of the $T$. maritima aspartate-semialdehyde dehydrogenase (Asd) gene. Asd is an enzyme involved in the biosynthesis of Llysine, L-methionine, L-threonine and L-isoleucine from aspartate. The amino acid sequence of the postulated $T$. maritima Asd fragment was $49 \%$ identical to residues 1-277 of the Vibrio cholerae Asd and shared more than $40 \%$ identity with the corresponding parts of various other known Asds (not shown). The deduced amino acid sequence of a small open reading frame downstream of cel $A$-celB displayed low-level similarity with a 141 residue, hypothetical protein ( $\mathrm{YjeB}$ ) of unknown function in the pur. $A-v a c B$ intergenic region of $E$. coli.

The DNA region upstream of cel $A$ contains nine $30 \mathrm{bp}$ direct repeats (Figs 1-3), seven of which are $100 \%$ identical. The repeats are separated by non-similar se- 
TOGAAGGTCAAAAAACATCTTGCTTTCAGAGTGTGTTGTGGTATAATTTCTTTTGAACT

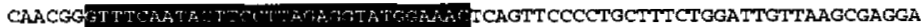

TCTTCCE'

TIGTCC

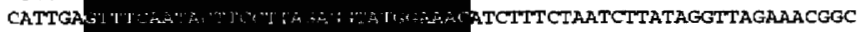

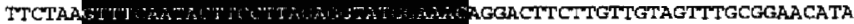

TCATAC TMT Th

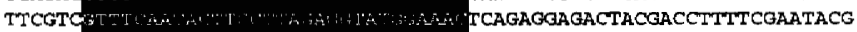

CCGACA T:

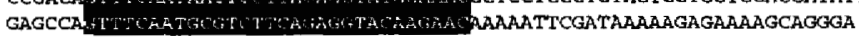

TTAATACCCCTGITTTTTTATTTTGGGTGTATTTAGTCTATTTGCOAATTTTCAGATTTTGAATGTAA

ACATTTTCATAATAAGATGTTTTCTGGAGGTARAATGGTGGTACTGATGACAAAACCGSGAACATCGGAT $\begin{array}{llllllllll}M & V & L & M & T & K & P & G & T & S\end{array}$
Consensus: GTTTCAATACTTCCTTAGAGGTATGGAAAC

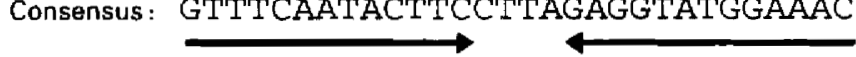

Fig. 3. Alignment of nine $30 \mathrm{bp}$ sequence repeats found upstream of celA. Repeats 1 through 7 are $100 \%$ identical, while repeats 8 and 9 have one and nine mismatches, respectively, when compared to the consensus. Each repeat can itself be considered to be a region with dyad symmetry, and is indicated by converging arrows drawn below the consensus.
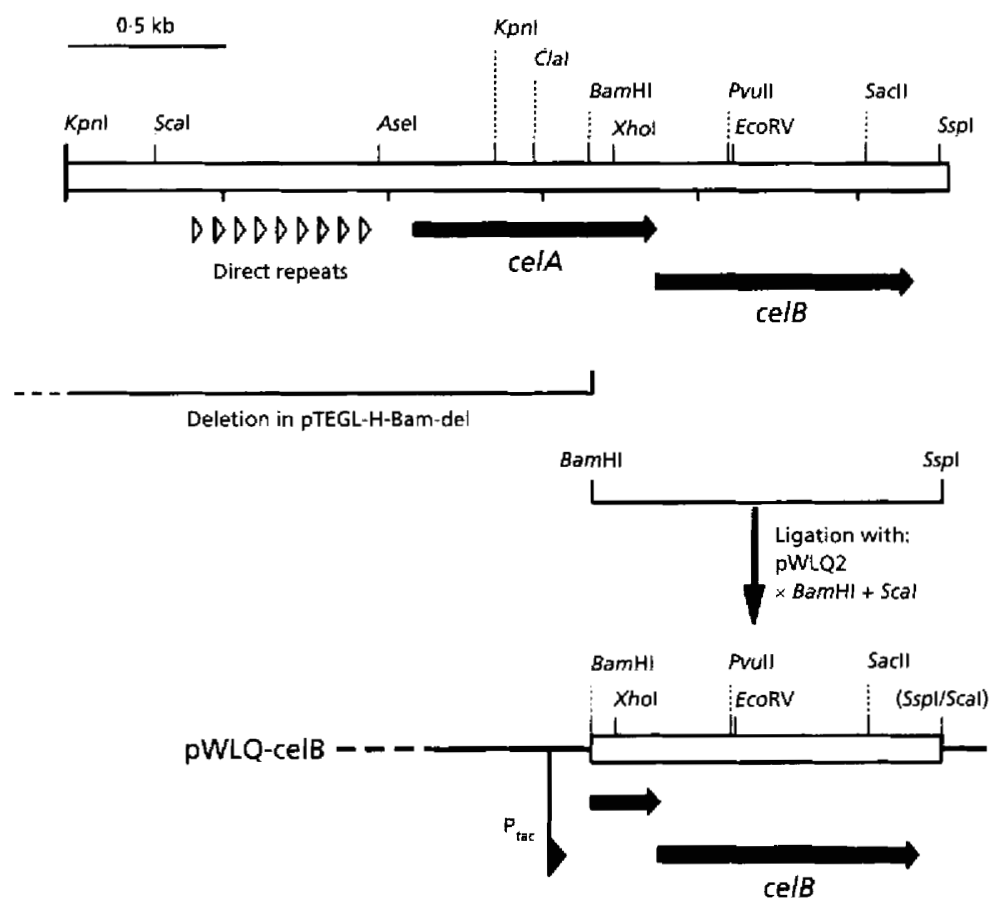

Fig. 4. Design of recombinant plasmids for determining whether ce/B represents a functional cellulase-encoding cistron. A restriction map of the $2.8 \mathrm{~kb}$ DNA fragment whose nucleotide sequence is shown in Fig. 3 is given. A deletion was introduced into pTEGL-H (Fig. 1) by BamHI digestion and religation, yielding pTEGL-H-Bam-del, which lacks most of celA but carries the complete cel $B$ open reading frame. For the construction of $\mathrm{pWLQ}$-celB, the cel $B$ gene was isolated as a BamHI-Sspl fragment and inserted in expression vector pWLQ2 downstream of the strong $P_{t a c}$ promoter. quences of $3441 \mathrm{bp}$. Interestingly, each repeat itself represents a sequence with imperfect dyad symmetry (Fig. 3). Although the function of the DNA sequence repeats is unknown, their vicinity to the $5^{\prime}$-end of the cel $A$-celB gene cluster makes it tempting to speculate that they may be involved in the regulation of cellulase expression.

\section{Separation from celA and functional heterologous expression of $c e / B$}

Sequence analysis of the open reading frame $c e l B$ immediately downstream of cel $A$ revealed that its translation product was nearly $50 \%$ identical to CelA, making it seem likely that it may encode another cellulase. This assumption was proven by expressing this gene after separation from cel $A$. For this purpose, we first tried to delete the DNA region upstream of the BamHI site (within the $c e / A$ gene at position 1664 of Fig. 2) in plasmid
p'EGL-H, which contains cel $A$ and celB. However, this deletion completely abolished thermostable cellulase production in the corresponding E. coli transformant. On the other hand, placement of celB (as a $1.1 \mathrm{~kb} \mathrm{BamHI-SspI}$ fragment of pTEGL-H; corresponds to residues 1664 2777 of Fig. 2) under the transcriptional control of the $\mathrm{P}_{\text {tac }}$ promoter of expression vector $\mathrm{pWLQ2}$ (Liebl et al., 1992) and transformation of the resulting plasmid pWLQcelB (Fig. 4) into E. coli XL1-Blue (Stratagene) resulted in a recombinant strain which produced thermostable CMcellulose-hydrolysing activity upon induction with IPTG (data not shown). This experiment clearly demonstrates that $c e l B$ represents an intact cellulase gene. The genetic organization of the analysed cellulase gene region suggests that $c e l B$ is co-transcribed with $c e l A$. Downstream of $c e / B$ a potential tho-independent terminator structure was detected (Fig. 2). As the ATG start codon of $c$ lB overlaps with the last glutamate codon and the stop codon of $c$ el. $A$, 
(a)

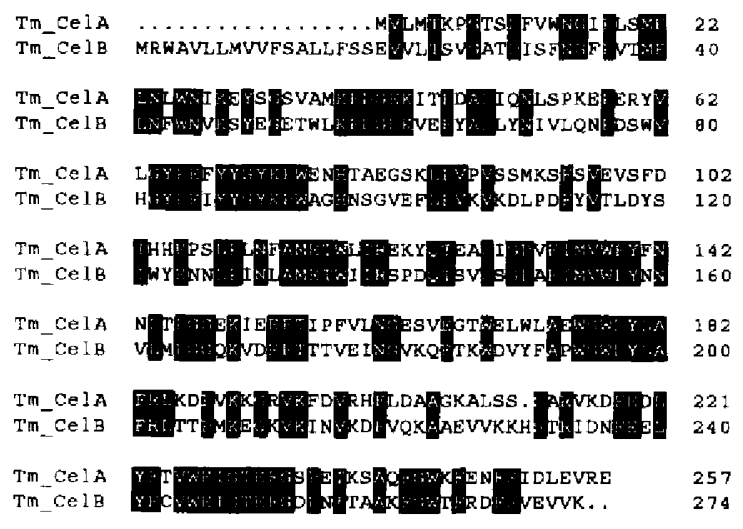

(b)

\begin{tabular}{|c|c|c|}
\hline$T m \_C e l A$ & 128 & NEI \\
\hline Tm_cels & 146 & $A B I M G Y$ \\
\hline Eca_cel & 252 & KYTSSVE F \\
\hline Aac_Cel & 128 & 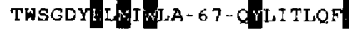 \\
\hline
\end{tabular}

Fig. 5. (a) Alignment of the amino acid sequences of CelA and CelB. Identical residues in both primary structures are indicated. (b) Local amino acid sequence similarity between $T$. maritima CelA (Tm_CelA), T. maritima CelB (Tm_CelB), Erwinia carotovora CelS (Eca_Cel) and an Aspergillus aculeatus cellulase (Aac_Cel). The $T$. maritima enzymes share only very low overall similarity with the other two cellulases. Therefore, only short stretches of sequences around two conserved glutamate residues which may be involved in the catalytic mechanism of the enzymes (see Saarilahti et al., 1990; Torronen et al., 1993) are shown here. The numbering of Eca_Cel and Aac Cel is according to sequences retrieved from the SWISS-PROT database, accession numbers $\mathrm{P} 16630$ and $\mathrm{P} 22669$, respectively.

translational coupling might also occur. Interestingly, the putative tibosome-binding sites of $c e l A$ and $c e l B$ appear to be identical, contained within an $11 \mathrm{bp}$ sequence (TCTGGAGGTGA) found $5 \mathrm{bp}$ and $4 \mathrm{bp}$, respectively, upstream of each of the corresponding start codons (Fig. 2).

\section{CelA and CelB have similar primary structures, but only CelB has an amino-terminal signal peptide}

The primary structures of CelA (257 residues; $29732 \mathrm{Da}$ ) and CelB (274 residues; $31732 \mathrm{Da}$ ) deduced from the nucleotide sequences of their genes are highly similar. The amino acid sequences can be aligned (Fig. 5a) with the introduction of merely one single-residue gap and share $49.8 \%$ identical residues $(68.8 \%$ similarity, if conservative exchanges are considered). Due to the high level of relatedness on the protein primary structure level as well as the nucleotide sequence level ( $58 \%$ identical), it seems likely that the $c e l A-c e l B$ gene cluster evolved via gene duplication from an ancestral cellulase gene. CelB, in contrast to CelA, carries a hydrophobic amino-terminal extension with all the features of typical signal peptides (von Heijne, 1985). The predicted signal peptidase cleavage site lies between serine residues 17 and 18 of CelB (see Fig. 2 or 5a). The putative mature polypeptide would therefore have a size of 257 amino acid residues with a calculated molecular mass of $29767 \mathrm{Da}$, which is almost the same as CelA (257 residues; $29732 \mathrm{Da}$ ). Thus it may be that the two products of the $T$. maritima cel $A-c e l B$ cellulase gene cluster are targeted to different cellular compartments. CelA (cellulase I) was originally isolated from a crude cellular extract of washed T. maritima MSB8 cells (Bronnenmeier et al., 1995), but detailed studies to elucidate the precise subcellular localization have yet to be performed. Due to its signal peptide, CelB is expected to be either a periplasmic or an extracellular enzyme. If CelA turns out to be a cytoplasmic $\beta$-glucanase, its physiological role could be the breakdown of cello-oligomers internalized by the cell.

\section{Amino acid sequence similarity between CelA and CelB and other proteins}

We attempted to find polypeptides related to CelA or CelB by searching through the available protein sequence databases (PIR, SWISS-PROT) using the standard search algorithms (programs FASTA and BI.ASTP). Only one enzyme, an endoglucanase of Erwinia carotovora, exhibited low but significant amino acid sequence similarity with CelA $(25.2 \%$ identity over the entire length of the polypeptide chains). This E. carotovora enzyme belongs to glycosyl hydrolase family 12 (Hentissat, 1991) and has only one known 'relative', a $\beta$-glucanase (FI-CMCase) of Aspergillus aculeatus. The amino acid sequence identities between T. maritima CelA and the latter enzyme, as well as between T. maritima CelB and the Erwinia and Aspergillus $\beta$-glucanases, are on the border of detection $(20-22 \%)$. However, all four enzymes share the two short peptide sequences shown in Fig. 5(b). Also, hydrophobic cluster analysis revealed significant similarity between the enzymes (data not shown). Therefore, we propose that CelA and CelB of $T$. maritima MSB8 belong to glycosyl hydrolase family 12 (corresponds to $\beta$-glycanase family $\mathrm{H}$; Gilkes et al., 1991; Henrissat, 1991), which doubles the number of known members of this small cellulase family.

It has been proposed by Törrönen et al., (1993) on the basis of hydrophobic cluster analysis that the lowmolecular-mass endo-xylanases comprising glycosyl hydrolase family 11 (corresponds to $\beta$-glycanase family $G$ ) and the two members of family 12 cellulases (family $\mathrm{H}$ ) known at that time shared weak but significant similarity. Members of both these enzyme families hydrolyse glycosidic bonds with retention of the anomeric configuration (Geblet $e t a l ., 1992$; Schou $t$ t al., 1993). For one family 11 enzyme, the Bacillus pumilus xylanase, the elucidation of the three-dimensional structure and site-directed mutagenesis studies have led to the identification of two glutamate residues essential for the general acid catalysis mechanism of this enzyme (Ko et al., 1992). By analysing similarity, Törrönen et al. (1993) predicted that the corresponding glutamate residues of the family 12 cellulases ( $\mathrm{Glu}_{158}$ and $\mathrm{Glu}_{246}$ for E. carotovora CelS, Glu ${ }_{134}$ and Glu $_{218}$ for $A$. aculeatus FI-CMCase) are essential for the catalytic activity of these enzymes. The fact that both $T$. maritima cellulases also have glutamate residues at the 


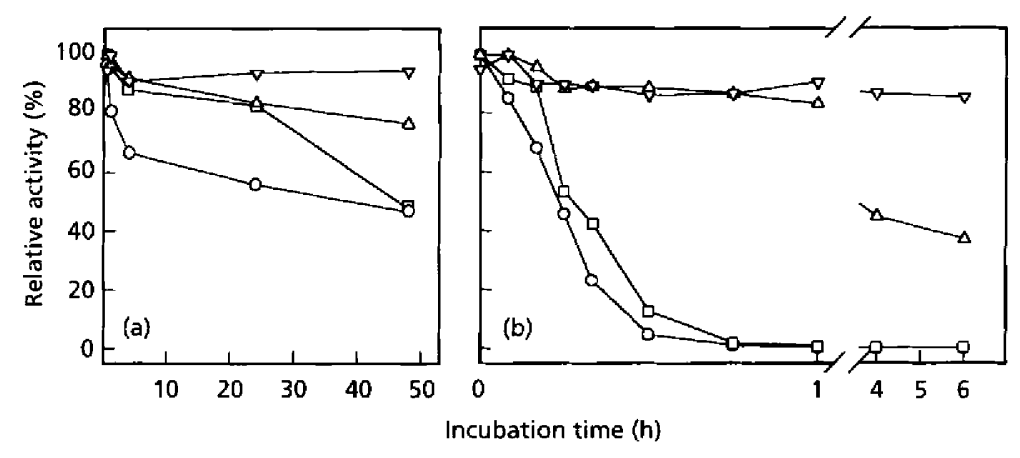

Fig. 6. Thermostability of purified CelA at $85^{\circ} \mathrm{C}$ (a) and $95^{\circ} \mathrm{C}$ (b) at various $\mathrm{NaCl}$ concentrations $(O$, none; $\square, 1 \mathrm{M} ; \triangle, 2.5 \mathrm{M}$; $\nabla, 5 \mathrm{M})$. The data represent the means of duplicate assays. The highest activity at each salt concentration was defined as $100 \%$. Note the different time scales in the graphs.

corresponding positions ( $\mathrm{Glu}_{134}$ and $\mathrm{Glu}_{231}$ for CelA, $\mathrm{Glu}_{152}$ and $\mathrm{Glu}_{250}$ for CelB; see Fig. 5b) strengthens the hypothesis that these are indeed the catalytically essential acidic residues of family 12 glycosyl hydrolases (family $\mathrm{H}$ $\beta$-glycanases).

Comparison of the amino acid compositions of CelA and CelB with the less thermostable cellulases of family 12 revealed some differences, for example an increased percentage of the charged residue glutamate $(1.8 \mathrm{~mol} \%$ for $A$. aculeatus FI-CMCase and $3.4 \mathrm{~mol} \%$ for E. carotovora CelS versus $10.9 \mathrm{~mol} \%$ for T. maritima CelA and 8.2 $\mathrm{mol} \%$ for $T$. maritima $\mathrm{CelB}$ ), and a slight increase in proline $(3.2 \mathrm{~mol} \%$ and $2.6 \mathrm{~mol} \%$, versus $5.5 \mathrm{~mol} \%$ and $4.7 \mathrm{~mol} \%$, respectively). However, it is not possible to tell if these differences could account for the extreme thermostability of CelA and CelB because the set of data is too small for a statistically significant analysis, and the degree of relatedness between the Thermotoga cellulases and their mesophile counterparts is too low to even construct reliable full-length pairwise alignments. Therefore, these observations must be interpreted with caution until more primary structures, or preferably highresolution three-dimensional structures, of family 12 cellulases of mesophilic and thermophilic origin become available.

\section{Purification and characterization of the recombinant $\boldsymbol{\beta}$-glucanase CelA}

In order to increase the recombinant enzyme level, the cel $A$-coding region was amplified from $\mathrm{PTEGL}-\mathrm{H}$ via PCR and inserted downstream of the transcription and translation initiation signals of expression vector $\mathrm{p}$ T7-7, yielding the plasmid pT7-7-celA (see Methods). p'T7-7celA was introduced into the expression host E. coli $\mathrm{BL} 21$, which carries an IPTG-inducible copy of the phage T7 RNA polymerase gene. Unexpectedly, induction of $\mathrm{P}_{\mathrm{T}^{-}}$ driven expression by addition of $0.4 \mathrm{mM}$ IPTG in the exponential growth phase of E. coli BL21(pT7-7-celA) resulted in severe growth impairment of the host strain. However, the basal expression level without induction was high enough to allow the purification of the recombinant cellulase. A preliminary enzyme localization experiment with a different strain (E. coli M5219/pTg1) had revealed that the majority of the thermostable $\beta$ - glucanase was cell-associated, and only about $9 \%$ of the activity was released by cold osmotic shock (not shown). Therefore, the $\beta$-glucanase was purified from a whole-cell lysate of E. coli BI.21(pT7-7-celA) by heat precipitation, anion-exchange chromatography and hydrophobic interaction chromatography as described in Methods. Starting with about $4 \mathrm{~g}$ total protein, about $17 \mathrm{mg}$ pure CelA was obtained (Table 1). The specific CM-cellulosehydrolysing activity of this preparation was $291 \mathrm{U}$ (mg protein $)^{-1}$. Amino-terminal sequencing of the purified recombinant celluiase yielded the sequence MVLMTKPGTSDFVWNGIPLS for the first 20 residues, which corresponds precisely to the result expected on the basis of the nucleotide sequence of the gene (see Fig. 2) and contains the 12 residue sequence also obtained by sequencing of the authentic cellulase purified from $T$. maritima cells (see above). Recombinant CelA production in E. coli led to an enzyme preparation which was aminoterminally heterogeneous. In addition to the expected residue, each sequencing cycle yielded a second amino acid derivative corresponding to the next residue of the sequence, meaning that a significant proportion of the CelA molecules lacked the amino-terminal methionine residue.

The recombinantly produced CelA had an apparent molecular mass of about $30 \mathrm{kDa}$ as determined by SDSPAGE analysis (not shown), which corresponds well with the value expected from the nucleotide sequence of the gene $(29732 \mathrm{Da})$ and the size of the authentic enzyme from $T$. maritima cells (cellulase I; Bronnenmeier $e t$ al., $1995)$. Using the substrates $\beta$-glucan, $p$-nitrophenyl $\beta$-Dcellobioside and xylan, CelA displayed a broad range of near-maximum $(>75 \%)$ activity between $\mathrm{pH} 6.0$ and 8.5 (data not shown). With CM-cellulose as the substrate, the $\mathrm{pH}$ optimum was shifted to more acidic conditions ( $\mathrm{pH} 4 \cdot 5-6 \cdot 5)$. A substrate-dependent shift in the $\mathrm{pH}$ activity profile has been reported before for a $\beta$-glucanase (Hitomi et al., 1994) and has also been described for mammalian $\alpha$-amylases (Ishikawa et al., 1990, 1993). This phenomenon may be caused by pH-dependent differences in the binding affinities of substrate-binding subsites of these enzymes for different substrates. The "temperature optimum' of CelA, which was determined in $30 \mathrm{~min}$ assays in $50 \mathrm{mM}$ MES buffer, $\mathrm{pH} 6.0$, with $1 \% \mathrm{CM}$ cellulose, was about $90^{\circ} \mathrm{C}$. 
Table 2. Substrate specificity of the T. maritima $\beta$-glucanases CelA and CelB

Assays were performed at substrate concentrations of $4 \mathrm{mM} p$-nitrophenyl $\beta$-D-cellobioside, $1 \%(\mathrm{w} / \mathrm{v}$ ) non-soluble polymeric substrates or $0.5 \%(\mathrm{w} / \mathrm{v}$ ) soluble polymers in $50 \mathrm{mM}$ MES buffer, $\mathrm{pH} 6.0$, at $85^{\circ} \mathrm{C}$ using an enzyme concentration of $81 \mathrm{ng} \mathrm{ml}^{-1}$ (purified CelA) or $3 \mu \mathrm{g} \mathrm{ml}^{-1}$ (crude CelB). Incubation was carried out for $10-60 \mathrm{~min}$ for $\beta$-glucan, CM-cellulose and $p$-nitrophenyl $\beta$-Dcellobioside, $24 \mathrm{~h}$ for xylan and acid-swollen Avicel, and up to $48 \mathrm{~h}$ for Avicel and cellulose MN300. Activity on barley $\beta$-glucan was defined as $100 \%$.

\begin{tabular}{|c|c|c|c|c|}
\hline \multirow[t]{2}{*}{ Substrate } & \multicolumn{2}{|c|}{ CelA } & \multicolumn{2}{|c|}{ CelB } \\
\hline & $\begin{array}{c}\text { Specific } \\
\text { activity } \\
\left(\mathbf{U} \mathrm{mg}^{-1}\right)\end{array}$ & $\begin{array}{l}\text { Relative } \\
\text { activity } \\
(\%)\end{array}$ & 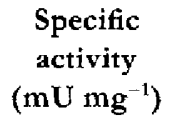 & $\begin{array}{c}\text { Relative } \\
\text { activity } \\
(\%)\end{array}$ \\
\hline Barley $\beta$-glucan & 1785 & 100 & 2905 & 100 \\
\hline CM-cellulose & 302 & 17 & 890 & $30 \cdot 6$ \\
\hline$p$-Nitrophenyl & $7 \cdot 4$ & 0.42 & 50 & $1 \cdot 70$ \\
\hline \multicolumn{5}{|l|}{$\beta$-o-cellobioside } \\
\hline Acid-swollen Avicel & 8.0 & $0 \cdot 48$ & 26 & 0.89 \\
\hline Avicel & 0 & 0 & 0 & 0 \\
\hline Cellulose MN300 & 0 & 0 & 0 & 0 \\
\hline Oat spelts xylan & $2 \cdot 5$ & $0 \cdot 14$ & 8 & $0-28$ \\
\hline
\end{tabular}

\section{Thermostability of recombinant CelA}

Purified CelA was incubated at a concentration of $1.6 \mu \mathrm{g}$ $\mathrm{ml}^{-1}$ in $50 \mathrm{mM}$ MES, $\mathrm{pH} 6.0$, containing $0,1,2.5$ or $5 \mathrm{M}$ $\mathrm{NaCl}$ at 70,85 or $95^{\circ} \mathrm{C}$. After various periods of time, the temaining $\mathrm{CM}$-cellulose-hydrolysing activity was determined under standard assay conditions $\left(\mathrm{pH} 6.0,85^{\circ} \mathrm{C}\right.$ ). At $70^{\circ} \mathrm{C}$, the enzyme was stable over a period of at least $56 \mathrm{~h}$ at all $\mathrm{NaCl}$ concentrations tested (data not shown). At $85^{\circ} \mathrm{C}$ in the absence of $\mathrm{NaCl}$ or at $1 \mathrm{M} \mathrm{NaCl}$, CelA still displayed remarkable thermostability, showing mote than $40 \%$ of its initial activity after a $48 \mathrm{~h}$ incubation, whereas at $95{ }^{\circ} \mathrm{C}$ under otherwise identical conditions the enzyme was inactivated within about $30 \mathrm{~min}$ (Fig. 6). The addition of high salt concentrations led to a dramatic increase in thermostability. At $5 \mathrm{M} \mathrm{NaCl}$, the activity of CelA was not significantly reduced after $6 \mathrm{~h}$ at $95^{\circ} \mathrm{C}$ (Fig. 6). The protein-stabilizing effect brought about by the addition of certain salting-out co-solvents such as $\mathrm{MgSO}_{4}$ or $\mathrm{NaCl}$ was recently reviewed by Timasheff (1993).

\section{Substrate specificity and hydrolysis products}

The relative rates of hydrolysis of a variety of substrates are summarized in Table 2 . Like many other $\beta$-glucanases, $T$. maritima CelA displayed much higher activity with barley $\beta$-glucan, a 1,4- $\beta-/ 1,3-\beta$-mixed linkage substrate, than with the modified cellulose model substrate $\mathrm{CM}$ cellulose. $\alpha$-Glucans like soluble starch or pullulan were not attacked. The products formed during hydrolysis of barley $\beta$-glucan were analysed by TLC (not shown). The initial products resolved with this technique were a mixture of oligosaccharides with a degree of polymerization (DP) of 3 and larger. The major products after extended incubation were tri- and tetrasaccharides, but a substantial amount of DP 2 oligosaccharides and some glucose were also formed. Based on these data, we conclude that CelA probably represents an endo- $\beta$-glucanase $(1,4-\beta$-D-glucan glucanohydrolase; EC 3.2.1.4). Hydrolysis of $p$-nitrophenyl $\beta$-D-cellobioside, which is often used as a model substrate for exo- $\beta$ glucanases, was also observed. However, the differentiation of exo- and endocellulases on the basis of their specificities using small soluble substrates does not appear to be a very useful method (see Claeyssens \& Henrissat, 1992) and therefore does not contradict the classification of CelA as an endoglucanase. The enzyme apparently is not strictly specific for $1,4-\beta$-D-glucosidic bonds because oat spelts xylan, a polymer consisting predominantly of $1,4-\beta$-linked xylose units, was also hydrolysed, although with low catalytic efficiency (Table 2). Xylan hydrolysis has also been observed with E carotovora CelS (Saarilahti et al., 1990), a distantly related endoglucanase belonging to the same enzyme family as $\operatorname{Cel} A$ (see above).

\section{Comparison of CelA and CelB properties}

Some properties of recombinant CelB were determined in order to compare this enzyme with the structurally similar enzyme CelA. For this purpose, cells of E. coli XL1Blue(pWLQ-celB) (see above and Fig. 4) were grown to the exponential growth phase and induced with IPTG. CelB was prepared from crude lysate by heat treatment at $70^{\circ} \mathrm{C}$ for $20 \mathrm{~min}$ and removal of precipitated proteins (typically $90-95 \%$ of the host proteins) by centrifugation. The specific CM-cellulose-hydrolysing activity of this crude CelB preparation was $0.89 \mathrm{U}$ (mg protein) ${ }^{-1}$ (determined in $50 \mathrm{mM} \mathrm{MES}$, $\mathrm{pH} 6.0$, at $85^{\circ} \mathrm{C}$ ). The 'temperature optimum' $\left(85-90^{\circ} \mathrm{C}\right)$ and substrate specificity (Table 2) of CelB were similar to CelA. However, $\mathrm{Cel} A$ and $\mathrm{CelB}$ differed significantly in their $\mathrm{pH}$-activity profiles 


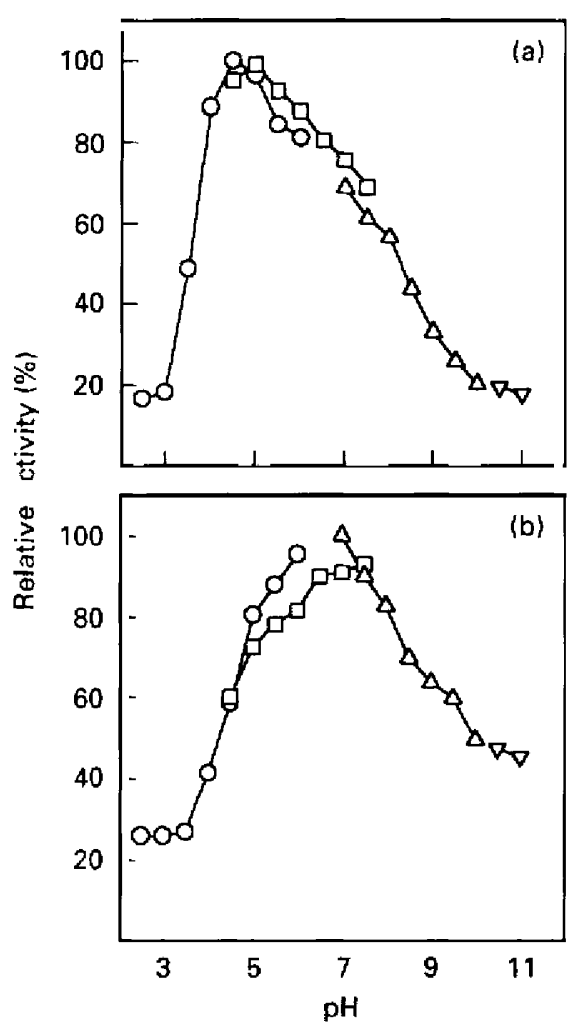

Fig. 7. Effect of $\mathrm{pH}$ on the hydrolysis of $\mathrm{CM}$-cellulose by CelA (a) and CelB (b). The buffers used were succinate/ $\mathrm{NaOH}$ (O) pH 3.0-6.0), MES/NaOH ( $\square$; pH 4.5-7.0), Tris/HCl $(\triangle$; $\mathrm{pH} 7.0-10-0)$ and glycine/ $\mathrm{NaOH}(\nabla ; \mathrm{pH} \mathrm{10-5-11 \cdot 0)}$. The assays were performed at $80^{\circ} \mathrm{C}$.

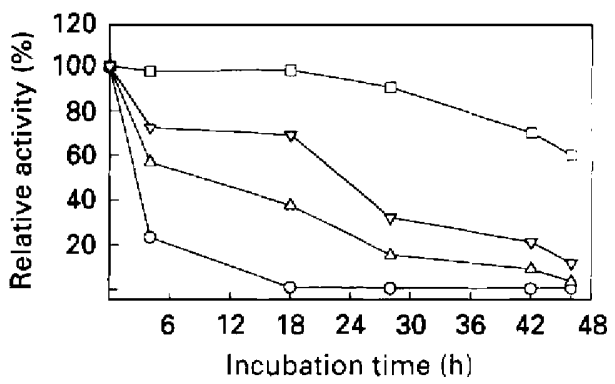

Fig. 8. Long-term thermostability of CelA $(O, \sqsupset)$ and CelB $(\triangle$, $\nabla)$ at $90^{\circ} \mathrm{C}$. After preincubation of enzyme $(1.6 \mu \mathrm{g}$ pure CelA $\mathrm{ml}^{-1}$ or $4.5 \mu \mathrm{g}$ crude $(\mathrm{elB} \mathrm{ml}-1)$ for various periods of time in the presence of $2.5 \mathrm{M} \mathrm{NaCl}(\square, \nabla)$ or without the addition of salt $(0, \triangle)$, residual activities were determined under standard assay conditions. The highest activity at each salt concentration was defined as $100 \%$.

(Fig. 7) and long-term thermostability (Fig. 8). Also CelB was less well stabilized by salt addition than CelA (Fig. 8). Since mictocrystalline cellulose was not significantly hydrolysed by CelB (Table 2), this enzyme apparently does not tepresent cellulase Il isolated previously (Bronnenmeier $e t$ al., 1995) from T. maritima MSB8 cells.
It seems quite obvious to us that the highly similar, adjacent cellulase genes $c / A$ and $c / B$ of $T$. maritima MSB8 arose from a single predecessor gene, possibly by a recent gene duplication event. Depending on the starting scenario, one of the genes subsequently must have either lost or acquired an in-frame signal-peptide-coding region. It would be interesting to obtain more information about the precise localization of the structurally similar enzymes CelA and CelB in T. maritima cells in order to obtain clues about possible differences in their physiological roles. Also, the function of the unusual multiple sequence repeats upstream of the $c e l A-c e l B$ gene cluster has yet to be solved.

\section{ACKNOWLEDGEMENTS}

Technical assistance by $B$. Schumacher is gratefully acknowledged. This work was supported by the Deutsche Forschungsgemeinschaft (SFB 145-B9 and YW4; Br 1472/2; I.i$398 / 3)$.

\section{REFERENCES}

Ausubel, F. M., Brent, R., Kingston, R. E., Moore, D. D., Seidman, J. G., Smith، J. A. \& Struhl, K. (1987). Current Protocols in Molecular Biology. New York: John Wiley and Sons.

Bernfeid, P. (1955). Amylases $\alpha$ and $\beta$. Metbods Enzymol 1, 149-158.

Bradford, M. M. (1976). A rapid and sensitive method for the quantitation of microgram quantities of protein utilizing the principle of protein-dye binding. Anal Biochem 72, 248-254.

Bronnenmeier, K., Kern, A., Liebl, W. \& Staudenbauer, W. (1995). Purification of Thermotoga maritima enzymes for the degradation of cellulosic materials. Appl Environ Microbiol 61, 13991407.

Claeyssens, M. \& Henrissat, B. (1992). Specificity mapping of cellulolytic enzymes: classification into families of structurally related proteins confirmed by biochemical analysis. Protein Soi 1 , 1293-1297.

Dakhova, O. N., Kurepina, N. E., Zverlov, V. V., Svetlichnyi, V. A. \& Velikodvorskaya, G. A. (1993). Cloning and expression in Escherichia coli of Thermotoga neapolitana genes coding for enzymes of carbohydrate substrate utilization. Biochem Biopbys Res Commun 194, $1359-1364$

Devereux, J., Haeberli, P. \& Smithies, O. (1984). A comprehensive set of sequence analysis programs for the VAX. Nucleic Acids Res $12,387-395$.

Gabelsberger, J., Liebl, W. \& Schleifer, K. H. (1993a). Cloning and chatacterization of $\beta$-galactoside and $\beta$-glucoside hydrolysing en zymes of Thermatoga maritima. FEMS Microbiol Lett 109, 131-138.

Gabelsberger, J., Liebl, W. \& Schleifer, K. H. (1993b). Purification and properties of recombinant $\beta$-glucosidase of the hyperthermophilic bacterium. Thermotoga maritima. Appl Microbiol Biotechnol 40 , 44-52.

Gebler, J., Gilkes, N. R., Claeyssens, M., Wilson, D. B., Béguin, P., Wakarchuk, W. W., Kilburn, D. G., Miller, R. C., Jr, Warren, R. A. J. \& Withers, S. G. (1992). Stereoselective hydrolysis caralyzed by relared $\beta$-1,4-glucanases and $\beta-1,4$-xylanases. I Biol Chem 267, $12559-12561$.

Gilkes, N. R., Henrissat, B., Kilburn, D. G., Miller, R. C., Jr \& Warren, R. A. J. (1991). Domains in microbial $\beta-1,4$-glycanases: 
sequence conservation, function, and enzyme families. Microbiol Rev 55, 303-315.

von Heijne, G. (1985). Signal sequences. The limits of variation. $J$ Mol Biol 184, 99-105.

Henrissat, B. (1991). A classification of glycosyl hydrolases based on amino acid sequence similarities. Biochem $J$ 280, 309-316.

Hitomi, J., Park, J.-S., Nishiyama, M., Horinouchi, S. \& Beppu, T. (1994). Substrate-dependent change in the $\mathrm{pH}$-activity profile of alkaline endo-1,4- $\beta$-glucanase from an alkaline Bacillus sp. J Biochem 116, 554-559.

Huber, R. \& Stetter, K. O. (1992). The Order Thermotogales. In The Procaryotes. A Handbook on the Biology of Bacteria, Ecopbysiology, Isolation, Identification, Applications, 2nd edn, vol. II, pp. 3809-3815. Edited by A. Balows, H. G. Trüper, M. Dworkin, W. Harder \& K. H. Schleifer. New York: Springer-Verlag.

Ishikawa, K., Matsui, I. \& Honda, K. (1990). Substrate-dependent shift of optimum $\mathrm{pH}$ in porcine pancreatic $\boldsymbol{x}$-amylase-catalyzed reactions. Biocbemistry 29, 7119-7123.

Ishikawa, K., Matsui, I., Kobayashi, S., Nakatani, H. \& Honda, K. (1993). Substrate recognition at the binding site in mammalian pancreatic $\alpha$-amylases. Biochemistry 32, 6259-6265.

Jaenicke, R. (1993). Structure-function relationship of hyperthermophilic enzymes. In Biocatalyst Design for Stability and Specificity, pp. 53-67. Edited by M. E. Himmel \& G. Geogious. ACS Sympositum Series No. 516. American Chemical Society.

Ko, E. P., Akatsuka, H., Moriyama, H., Shinmyo, A., Hata, Y., Katsube, Y., Urabe, I. \& Okada, H. (1992). Site-directed mutagenesis of aspartate and glutamate residues of xylanase from Bacillus pumilus. Biocbem J 288, 117-121.

Laemmli, U. K. (1970). Cleavage of structural proteins during the assembly of the head of bacteriophage T4. Nature 227, 680 685 .

Liebl, W., Feil, R., Gabelsberger, J., Kellermann, J. \& Schleifer, K. H. (1992). Purification and characterization of a novel thermostable 4- $\boldsymbol{x}$-glucanotransferase of Thermotoga maritima cloned in Escherichia coli. Eur J Biachem 207, 81-88.

Liebl, W., Gabelsberger, J. \& Schleifer, K. H. (1994). Comparative amino acid sequence analysis of Thermotoga maritima $\beta$-glucosidase (BglA) deduced from the nucleotide sequence of the gene indicates distant relationship between $\beta$-glucosidases of the BGA family and other families of $\beta-1,4-$ glycosyl hydrolases. Mol Gen Genet 242, 111-115.

Nilsson, B., Uhlen, M., Josephson, S., Gatenbeck, S. \& Philipson, L. (1983). An improved positive selection plasmid vector con- structed by oligonucleotide mediated mutagenesis. Nucleic Acids Res 11, 8019-8030.

Ostendorp, R., Liebl, W., Schurig, H. \& Jaenicke, R. (1993). The Llactate dehydrogenase gene of the hyperthermophilic bacterium Thermotoga maritima cloned by complementation in Escherichia coli. Eur J Biochem 216, 709-715.

Remaut, E., Stanssens, P. \& Fiers, W. (1981). Plasmid vectors for high-efficiency expression controlled by the $\mathrm{P}_{\mathrm{I}}$ promoter of coliphage lambda. Gene 15, 81-93.

Ruttersmith, L. D. \& Daniel, R. M. (1991). Thermostable cellobiohydrolase from the thermophilic eubacterium Thermotoga sp. strain FjSS3-B.1. Biochem J 277, 887-890.

Ruttersmith, L. D. \& Daniel, R. M. (1993). Thermostable $\beta$ glucosidase and $\beta$-xylosidase from Thermotoga sp. strain FiSS3-B.1. Biochim Biopbys Acta 1156, 167-172.

Saarilahti, H. T., Henrissat, B. \& Palva, E. T. (1990). CelS; a novel endoglucanase identified from Erwinia carotowna subsp. caratonora. Gene 90, 9-14.

Schou, C., Rasmussen, G., Kaltoft, M.-B., Henrissat, B. \& Schülein M. (1993). Stereochemistry, specificity and kinetics of the hydrolysis of reduced cellodextrins by nine cellulases. Eur J Biocbem 217, $947-953$

Schuller, A., Harkness, R. E., Rüther, U. \& Lubitz, W. (1985). Deletion of C-terminal amino acid codons of PhiX174 gene E: effect on its Iysis inducing properties. Nucleic Acids Res 13, $4143-4152$

Studier, F. W. \& Moffatt, B. A. (1986). Use of bacteriophage T7 RNA polymerase to direct selective high-level expression of cloned genes. J Mol Biol 189, 113-130.

Timasheff, S. N. (1993). The control of protein stability and association by weak interactions with water : how do solvents affect these processes? Annu Rev Biopbys Biomal Struct 22, 67-97.

Törönen, A., Kubicek, C. P. \& Henrissat, B. (1993). Amino acid sequence similarities between low molecular weight endo-1,4- $\beta$ xylanases and family $F$ cellulases revealed by clustering analysis. FEBS Lett 321, 135-139.

Wrba, A., Jaenicke, R., Huber, R. \& Stetter, K. O. (1990). Lactate dehydrogenase from the extreme thermophile Tbermotoga maritima. Eur J Biocbem 188, 195-201.

Yanisch-Perron, C., Vieira, J. \& Messing, J. (1985). Improved M13 phage cloning vectors and host strains: nucleotide sequence of the M13mp18 and pLC19 vectors. Gene 33, 103-119.

Received 22 February 1996; revised 7 May 1996; accepted 15 May 1996. 